\title{
IMPLEMENTASI PROGRAM PEMBANGUNAN INFRASTRUKTUR PERDESAAN (PPIP) DI KABUPATEN TEMANGGUNG TAHUN 2014
}

\author{
Meida Anggraeni Setyowati ${ }^{1}$, Endang Larasati ${ }^{2}$
}

\begin{abstract}
Rural Infrastructure Development Program (PPIP) strives to establish and improve the quality of people's lives, either individually or in groups through participation in solving various problems related to poverty, women's empowerment and village left behind in an effort to improve the quality of life, independence and prosperity. Location of Rural Infrastructure Development Program (PPIP) spreads in 29 provinces, targeting locations follow the provisions Minister Decree of Public Works with Public Works Minister's decision regarding the determination target villages of Rural Infrastructure Development Program (PPIP). Which is basically establishes village recipients list of programs then called as Rural Target of Rural Infrastructure Development Program (PPIP). The purpose of this study is to describe and analyze the implementation of the Rural Infrastructure Development Program (PPIP) in Temanggung District; and analyzes factors that support and inhibit the success of the Rural Infrastructure Development Program (PPIP) in TemanggungDistrict. The driving factors of this policy is good communication and disposition of Rural Infrastructure Development Program (PPIP) from implementor namely Public Works Department of Temanggung to the public as the program implementers i.e. Getas rural communities. While the inhibiting factors are affected by a lack of human resources i.e. the number of employees who are considered insufficient to handle the number of programs in a relatively time together. Another inhibiting factor is the structure of bureaucracy, namely the division of duties and functions of officials and employees with each other, cross over the fieldoften occurred. Besides that, the prominent barriers which felt by rural communities is basic usage per sub-district as the main indicator of the disbursement of funds by terms or gradual disbursement system. According to the name of this policy, namely Rural Infrastructure Development Program (PPIP), the basis for the disbursement of funds should be per village, so that the implementation of the program can be run more effectively.
\end{abstract}

Keywords: Implementation, Policy, Rural Infrastructure Development Program (PPIP)

\footnotetext{
${ }^{1}$ Konsultan Kebijakan Publik, Kabupaten Temanggung

${ }^{2}$ Magister Administrasi Publik, Fakultas IImu Sosial dan IImu Politik, Universitas Diponegoro
} 


\section{PENDAHULUAN}

Pelaksanaan pembangunan di Indonesia ditandai dengan ketidakmerataan dan ketimpangan pembangunan terutama pembangunan di daerah perdesaan. Sedangkan sumber daya alam perdesaan merupakan aset yang sangat berharga dan strategis untuk menjamin kelestarian mata pencaharian masyarakat perdesaan yang menunjang perekonomian masyarakat. Kabupaten Temanggung merupakan salah satu Kabupaten yang mengalami dampak diberlakukannya UU no 32 tahun 2004 yang mana pelaksanaan pembangunan perdesaan melibatkan tiap level pemerintahan dimulai dari pemerintah kabupaten, kecamatan dan desa.

PPIP di Kabupaten Temanggung dimulai tahun 2010, Maksud dari Program Pembangunan Infrastruktur Perdesaan (PPIP) yaitu sebagai upaya mendukung percepatan penanggulangan kemiskinan dan memperkuat implementasi tata kelola pemerintahan yang baik (good governance). Sedangkan tujuan dari Program Pembangunan Infrastruktur Perdesaan (PPIP) adalah untuk mewujudkan peningkatan akses masyarakat miskin, hampir miskin, dan kaum perempuan, termasuk kaum minoritas terhadap pelayanan infrastruktur dasar perdesaan berbasis pemberdayaan masyarakat dalam tata kelola pemerintahan yang baik.

Dalam kurun waktu 5 tahun Program Pembangunan Infrastruktur Perdesaan (PPIP) masih ada beberapa desa yang relatif rendah belum mendapatkan bantuan secara maksimal. Dari segi pertumbuhan ekonomi pembagian bantuan Program Pembangunan Infrastruktur Perdesaan (PPIP) di beberapa kecamatan di Kabupaten Temanggung, Kecamatan Temanggung termasuk kecamatan yang maju dan berbanding terbalik dengan Kecamatan Kaloran yang cenderung relatif tertinggal. Kurangnya ketersediaan infrastruktur yang memadai, terutama di daerah perdesaan yang berdampak pada perekonomian masyarakat perdesaan. Program pemerintah dalam meningkatkan pembangunan infrastruktur di perdesaan yaitu Program Pembangunan Infrasruktur Perdesaan (PPIP). Program Pembangunan Infrasruktur Perdesaan (PPIP) berupaya menciptakan dan meningkatkan kualitas kehidupan masyarakat baik secara individu maupun kelompok melalui partisipasi masyarakat.

Permasalahan yang dihadapi dalam pembangunan terutama pembangunan didaerah perdesaan masih ada ketimpangan pembangunan di kecamatan di Kabupaten Temanggung, terlihat masih ada kecamatan yang tergolong maju mendapatkan lebih 
banyak bantuan dari Program Pembangunan Infrastruktur Perdesaan (PPIP) sedangkan di kecamatan yang relatif tertinggal mendapatan sedikit bantuan dari pemerintah. Pembagian desa sasaran Program Pembangunan Infrastruktur Perdesaan (PPIP) di Kabupaten Temanggung tidak merata terlihat beberapa kecamatan yang pertumbuhan ekonominya rendah masih belum mendapat bantuan secara maksimal. Untuk itu perlu dikaji lebih lanjut mengenai implementasi Program Pembangunan Infrastruktur Perdesaan (PPIP) di Kabupaten Temanggung hal ini terkait dengan sesuai atau tidaknya pelaksanaan program dan faktor yang mendorong dan menghambat Program Pembangunan Infrastruktur Perdesaan (PPIP).

Berdasarkan hal tersebut, peneliti tertarik untuk mengkaji lebih lanjut mengenai pelaksanaan Program Pembangunan Infrastruktur Perdesaan (PPIP) dalam penelitian yang berjudul "Implementasi Program Pembangunan Infrastruktur Perdesaan (PPIP) di Kabupaten Temanggung Tahun 2014".

\section{Metode Penelitian}

\section{Jenis penelitian}

Peneliti menggunakan metode penelitian kualitatif dengan menggunakan pendekatan deskriptif.

\section{Fokus Penelitian}

Fokus penelitian yang diambil adalah Implementasi Kebijakan Program Pembangunan Infrastruktur Pedesaan (PPIP) di Kabupaten Temanggung Tahun 2014.

\section{Lokasi Penelitian}

Penelitian ini dilaksanakan di Kabupaten Temanggung. Dinas yang menjadi lokasi penelitian adalah Dinas Pekerjaan umum di jalan Pahlawan No. 21 Kabupaten Temanggung.

\section{Fenomena Pengamatan}

Fenomena yang diamati dalam penelitian yaitu bagaimana Implementasi Kebijakan Program Pembangunan Infratruktur Perdesaan (PPIP) di Kabupaten Temanggung dan fenomena yang timbul dalam penelitian ini yang mendukung dan menghambat pada implementasi Program Pembangunan Infratruktur Perdesaan (PPIP).

\section{Jenis dan Sumber Data}

Dalam penelitian ini menggunakan dua jenis data yaitu data primer dan data sekunder. Data primer adalah data utama yang diperoleh secara langsung dari informan 
melalui wawancara. Dan data Sekunder adalah data yang diperoleh secara tidak langsung dari objek penelitian melalui dokumen-dokumen.

\section{Pemilihan Informan}

Pengambilan informan dilakukan dengan pertimbangan pada kebutuhan data yang ingin diperoleh yang mengacu pada permasalahan yang digarap dalam penelitian ini. Jumlah masyarakat yang akan dijadikan informan dalam penelitian adalah menggunakan teknik purposif.

\section{Instrumen Penelitian}

Instrumen utama dalam penelitan ini adalah peneliti sendiri, peneliti melakukan perencanaan, pelaksanaan dan melakukan laporan hasil penelitian. Sedangkan alat yang dipakai dalam penelitian ini adalah pedoman wawancara, pedoman observasi dan pedoman penilaian dokumen yang dilengkapi alat perekam (kamera dan tape recorder) dan alat pencatat lain yang diperlukan selama wawancara atau observasi berlangsung.

\section{Teknik Analisis Data}

Dalam penelitian ini teknik yang digunakan dalam pengolahan data menggunakan reduksi data, sajian data dan penarikan kesimpulan. Selanjutnya dalam analisis data penilis menggunakan teknik taksonomi karena pada penelitian ini, peneliti hanya fokus pada implementasi Program Pembangunan Infratruktur Perdesaan (PPIP) dengan menggunakan 4 variabel yang dijabarkan dalam komunikasi, sumber daya, sikap dan struktur birokrasi sebagaimana yang tertuang dalam teori Edward III.

\section{PEMBAHASAN}

\section{$\underline{\text { Standar Isi }}$}

Pelaksanaan Program Pembangunan Infrastruktur Perdesaan (PPIP) mengikuti arahan yang diberikan oleh Pemerintah Pusat dan Satuan Kerja Pemerintah Provinsi sesuai dengan buku Pedoman Pelaksanaan yang dikeluarkan oleh Direktur Jenderal Cipta Karya Kementerian Pekerjaan Umum dan Perumahan Rakyat.

\section{Aktor Yang Terlibat}

Sebagai aktor pelaksana program masyarakat dan Dinas Pekerjaan Umum terlibat langsung dalam pelaksanaanya. Dari tahap awal yaitu musyawarah desa untuk memberikan pengarahan tentang alur pelaksanaan program dengan awal pembentukan Organisasi Masyarakat setempat untuk penanggung jawab pelaksaan program. 


\section{Prosedur}

Prosedur program ini seperti kebijakan top-down, dengan terbitnya Surat Keputusan (SK) Menteri Pekerjaan Umum yang menginstruksikan pemberian bantuan untuk daerah-daerah sasaran tertentu. Akan tetapi terdapat faktor eksternal yaitu politik, yang mempengaruhinya. Program Pembangunan Infrastruktur Perdesaan (PPIP) merupakan program aspirasi dari anggota DPR pusat.

\section{Faktor Pendorong dan Penghambat Implementasi Program Pembangunan Infrastruktur Perdesaan (PPIP)}

\section{Komunikasi}

Komunikasi dalam implementasi Program Pembangunan Infrastruktur Perdesaan (PPIP) berjalan dengan baik. Komunikasi adalah salah satu kunci keberhasialan dalam sebuah program. Dengan komunikasi yang baik antara implementor dengan masyarakat program akan dapat tercapai sesuai dengn tujuan bersama.

\section{Sumber daya}

Sumberdaya, masalah yang mendasar dalam aspek sumber daya kepegawaian adalah jumlah pegawai yang tidak memadai untuk diberikan tambahan beban pekerjaan. Sumber daya finansial yang mengalami masalah dalam pencairan dana bantuan.

\section{Disposisi}

Masyarakat memberikan tanggapan yang positif terhadap program ini, dengan adanya program pemberdayaan masyarakat. Namun untuk selanjutnya, perlu dilakukan perbaikan, supaya sistem produk kebijakan ini dapat lebih efektif mencapai sasaran

\section{$\underline{\text { Struktur birokrasi }}$}

Pada saat pelaksanaan, terbentur dengan sejumlah pelaksanaan program-program baru atau program yang lain, sehingga tidak sesuai dengan hasil rapat. Masalah hanya terdapat pada tidak sesuainya tupoksi pejabat dan pegawai dengan pekerjaan yang dijalankan.

\section{Faktor Penghambat Implementasi Program Pembangunan Infrastruktur Perdesaan (PPIP) di Kabupaten Temanggung.}

\section{Sumber Daya}

Jumlah pegawai yang dianggap tidak mencukupi untuk menangani sejumlah program dalam waktu yang relatif berdekatan, adanya perubahan aturan internal KPPN 
(Kantor Pelayanan Perbendaharaan Negara) yang hanya memperbolehkan pencairan dana lebih terbatas yaitu bagi enam desa per hari, dan pencairan dana untuk pekerjaan fisik di tingkat desa yang menggunakan sistem termin (per tahap pekerjaan) namun dengan dasar indikator per Kecamatan.

\section{$\underline{\text { Struktur Birokrasi }}$}

Pembagian tugas pokok dan fungsi antara pejabat dan pegawai yang satu dengan yang lain, sering terjadi lintas bidang. Selain itu, terdapat ketidaksesuaian antara kebutuhan infrastruktur desa dengan data yang terdapat dalam pedoman juklak dari Pemerintah. Hambatan terakhir dalam aspek ini, dirasakan oleh pihak Pemerintah Desa mengenai adanya aturan (SOP) yang mewajibkan dana untuk operasional, hanya senilai 5 persen dari total bantuan 250 juta. Dengan kasus yang dialami Desa Getas yaitu rapat sejumlah 48 kali, anggaran senilai 5 juta tidak mencukupi pemenuhan kebutuhan, sehingga pihak Pemerintah Desa mengeluarkan dana tambahan dari kas desa.

\section{PENUTUP}

\section{Kesimpulan}

Program Pembangunan Infrastruktur Perdesaan (PPIP) di Temanggung pada tahun 2010-2014 sudah di implementasikan dengan baik. Terlihat dalam Program Pembangunan Infrastruktur Perdesaan (PPIP) di desa Getas Kecamatan Kaloran telah mencapai tujuan Program Pembangunan Infrastruktur Perdesaan (PPIP) diantaranya pengentasan kemiskinan dan pemberdayaan perempuan dalam program tersebut. Untuk yang pertama yaitu Pengentasan kemiskinan dengan cara menunjang perbaikan perekonomian masyarakat desa Getas. Berupa pembangunan jalan yaitu rabat beton yang sehari-hari digunakan masyarakat untuk pergi kesawah, ke pasar untuk menjual hasil penennya, pergi bekerja dan sebagaianya menjadi lebih efisien.

\section{Rekomendasi}

Dari deskripsi mengenai hambatan-hambatan yang menonjol dalam pelaksanaan Program Pembangunan Infrastruktur Perdesaan (PPIP) di Kabupaten Temanggung, diperoleh analisa untuk rekomendasi yaitu:

1) Dari aspek Sumber Daya, penambahan pegawai pada sub bagian cipta karya agar mempermudah dalam menjalankan tugas sehingga pegawai yang mengampu program yang diberikan dapat bekerja secara maksimal. Selain itu hambatan 
menonjol yang dirasakan oleh masyarakat desa adalah penggunaan dasar per Kecamatan sebagai indikator utama pencairan dana dengan sistem pencairan termin atau bertahap. Berdasarkan nama dari kebijakan ini yaitu Program Pembangunan Infrastruktur Perdesaan (PPIP), seharusnya dasar untuk pencairan dana adalah per desa, sehingga pelaksanaan program dapat berjalan lebih efektif. Selain itu, saat ini terdapat Undang-Undang Republik Indonesia Nomor 6 tahun 2014 tentang Desa, dimana pasal 1 ayat 12 dijelaskan adanya dukungan pemberdayaan masyarakat desa dari Pemerintah Pusat. Dengan perubahan indikator dasar dari per Kecamatan menjadi per Desa, merupakan salah satu wujud serius dari Pemerintah Pusat menjalankan amanat Undang-Undang tersebut.

2) Dari aspek Struktur Birokrasi, hambatan paling menonjol yang dikemukakan oleh pihak pemerintahan desa, terutama dalam konteks ini adalah Desa Getas, yaitu nilai dana operasional yang digunakan untuk rapat di desa, yang diambil dari dana bantuan 250 juta, sebesar 5 persen, dianggap sebagai kendala program ini, karena tidak mencukupi kebutuhan operasional rapat sebanyak 48 kali. Dengan adanya kasus seperti ini, seharusnya terjadi evaluasi secara struktur anggaran dari Pemerintah Kabupaten, Pemerintah Provinsi, dan Pemerintah Pusat, sebagai pihak yang bertanggungjawab atas terlaksana dan kelancaran PPIP, dengan mengalokasikan sebagian APBD Kabupaten dan Provinsi untuk membiayai operasional pelaksanaan serta merubah Standar Operasional Prosedur (SOP) yang dicantumkan dalam buku Pedoman Pelaksanaan Program Pembangunan Infrastruktur Perdesaan (PPIP), sehingga masyarakat desa tidak perlu mengurangi dana bantuan pembangunan infrastruktur.

\section{DAFTAR PUSTAKA}

Arikunto, Suharsimi, 2006, Prosedur Penelitian Suatu Pendekatan Publik (Edisi revisi VI), PT. Rineka Cipta, Jakarta.

Dunn, William. N, 2003, Analisis Kebijakan Publik, PT. Hanindita Graya Widya, Yogyakarta.

Dwiyanto, Agus, 2008, Mewujudkan Good Governance Melalui Pelayanan Publik, Gadjah Mada University Press, Yogyakarta. 
Islamy, M. Irfan, 2004, Prinsip-prinsip Perumusan Kebijakan Negara, Sinar Grafika, Jakarta.

Moleong, Lexy. J, 2009, Metodologi Penelitian Kualitatif, PT. Remaja Rosdakarya, Bandung.

Nazir, Moh, 2005, Metode Penelitian, Ghalia Indonesia, Jakarta.

Subarsono, A. G, 2008, Analisis Kebijakan Publik, Pustaka Pelajar, Yogyakarta.

Sugiyono, 2007, Statistik Untuk Penelitian, Alfabeta, Bandung. 